Journal of

Accident and

Emergency

Medicine 1994

11, 172-174

\title{
Contaminated casualties: are we prepared to receive them?
}

\author{
M.EDGELL \& M.R.JAMES
}

Department of Accident \& Emergency, Royal Preston Hospital, Sharoe Green Lane, Fulwood, Preston

\section{SUMMARY}

The NHS's reception of casualties contaminated by radiation is reviewed. The findings suggest that training, facilities and personal protection for hospital staff are inadequate.

Key words: contamination, decontamination, protection, radioactive

\section{INTRODUCTION}

It is a requirement of institutions where there exists a potential for accidents involving radioactive contamination to make contingency plans, including arrangements for hospital treatment of casualties and for the protection of their employees and the public.

In order to deal with incidents for which only limited contingency planning by operators is practicable, the National Arrangements for Incidents involving Radioactivity (NAIR) were devised in 1964 and were last revised in 1987 by which time they had been implemented on over 300 occasions. NAIR are designed to provide radiological advice and assistance to the police when no alternative source of assistance is readily available, when other plans have failed to operate properly or where delays are experienced in effecting them. ${ }^{1}$ Such occasions include damage to containers in transit and accidents to vehicles conveying radioactive substances in public places. Regional Health Authorities have the responsibility to draw up plans with District Health Authorities for designating hospitals for deconta-

Correspondence: M. Edgell, Registrar, Accident and Emergency Department, Royal Preston Hospital, Sharoe Green Lane, Fulwood, Preston PR2 4HT, UK mination and treatment of contaminated casualties ${ }^{2}$ for inclusion in the NAIR scheme. If, however, it is decided at the scene that the casualty requires urgent hospital treatment for any injuries, he should be taken to the nearest accident and emergency (A\&E) department. ${ }^{3}$ The Department of Health states that it is essential that the readiness of staff to perform the role of treatment and decontamination is maintained by adequate training and exercising. ${ }^{2}$ The authors conducted a survey to determine whether this is the case.

\section{METHODS}

The survey took the form of a questionnaire addressed to the named head of department of the 187 A\&E departments in England that treat over 30000 patients per year.

The questionnaire asked whether or not each department was designated to receive contaminated casualties and if it had done so. Other topics covered included the monitoring equipment available, staff protection equipment and facilities for decontamination which also had relevance to the management of other noxious but non-radioactive contamination. The ability of the department to cope with multiple casualties and the level of training for staff were also covered.

\section{RESULTS}

Of the 187 A\&E departments surveyed, 118 (63\%) replied. Of these hospitals, $42 \%$ were designated to receive contaminated casualties. As can be seen from the results tables, there was a marked difference in both the availability of equipment and the level of training between the designated and nondesignated centres.

Approximately three times the percentage of designated hospitals said they had access to medical

Table 1. Availability of monitoring equipment

\begin{tabular}{lcc}
\hline & $\begin{array}{c}\text { Designated } \\
\text { hospitals(\%) }\end{array}$ & $\begin{array}{c}\text { Non-designated } \\
\text { hospitals (\%) }\end{array}$ \\
\hline Medical physics & 61 & 19 \\
Monitors & 25 & 7 \\
None Known & 14 & 74 \\
\hline
\end{tabular}




\begin{tabular}{lcc}
\hline & $\begin{array}{c}\text { Designated } \\
\text { hospitals (\%) }\end{array}$ & $\begin{array}{c}\text { Non-designated } \\
\text { hospitals (\%) }\end{array}$ \\
\hline (1) Plastic sheeting or stated equivalent & 78 & 65 \\
(2) Hooded overalls or stated equivalent & 66 & 26 \\
(3) Boots/overshoes & 80 & 65 \\
Combination of (2) and (3) & 60 & 25 \\
Combination of (1), (2) and (3) & 54 & 22 \\
\hline
\end{tabular}

Table 2. Equipment to reduce spread of contamination
Table 3. Training facilities available to staff

\begin{tabular}{lcc}
\hline & $\begin{array}{c}\text { Designated } \\
\text { hospitals (\%) }\end{array}$ & $\begin{array}{c}\text { Non-designated } \\
\text { hospitals (\%) }\end{array}$ \\
\hline Printed Material & 82 & 47 \\
Talks & 48 & 19 \\
Video & 26 & 12 \\
Exercises & 42 & 7 \\
Printed Only & 36 & 25 \\
None & 2 & 41 \\
\hline
\end{tabular}

Table 4. Facilities to dispose of shower water

\begin{tabular}{lcc}
\hline & $\begin{array}{c}\text { Designated } \\
\text { hospitals (\%) }\end{array}$ & $\begin{array}{c}\text { Non-designated } \\
\text { hospitals (\%) }\end{array}$ \\
\hline Main drain or none & 76 & 94 \\
Containment & 16 & 6 \\
Separate Drain & 8 & 0 \\
\hline
\end{tabular}

physics or to monitoring equipment when compared with non-designated hospitals. However, even in the designated hospitals $39 \%$ of staff were unaware of access to medical physics and $75 \%$ of hospitals did not have monitoring equipment available to them (Table 1).

Table 2 shows that $46 \%$ of designated hospitals and $78 \%$ of non-designated hospitals lacked basic items of equipment to minimize the spread of contamination and protect staff. Training facilities (Table 3 ) were absent in $41 \%$ of non-designated hospitals with exercises only occurring in $7 \%$ of these hospitals. Training facilities appear to be much better in the designated hospitals, $42 \%$ of which undertook exercises.

The vast majority of hospitals disposed of contaminated shower water down the main drain with only $6 \%$ of the non-designated hospitals and $16 \%$ of the designated hospitals using a containment system, although $8 \%$ of the designated hospitals did have a separate drain (Table 4). Although the majority $(76 \%)$ of designated hospitals use a specific room for decontamination only $35 \%$ of the nondesignated hospitals had this facility (Table 5).

Of those department surveyed $44 \%$ of the designated hospitals and $18 \%$ of the non-designated hospital felt that they could cope with multiple contaminated casualties.

\section{DISCUSSION}

Although accidents resulting in casualties contaminated by radioactivity are rare, $18 \%$ of designated hospitals in this survey have been required to treat them. Accidents during transport will continue to occur sporadically so that any A\&E department may be called on to treat the injured. The UK Atomic Energy Authority recently flew $500 \mathrm{~kg}$ of plutonium fuel rods to Scotland in containers designed to withstand a drop into an unyielding surface from a height of $9 \mathrm{~m}$ - equivalent to a 30 mile an hour impact - this meets current regulations and is not regarded as unsafe practice.

Hospitals are now required to comply with the Health And Safety At Work Regulations and must

\begin{tabular}{lcc}
\hline & $\begin{array}{c}\text { Designated } \\
\text { hospitals (\%) }\end{array}$ & $\begin{array}{c}\text { Non-designated } \\
\text { hospitals (\%) }\end{array}$ \\
\hline Designated room & 76 & 35 \\
Decontamination compounds & 42 & 25 \\
Specialist trolleys & 16 & 7 \\
Shower & 74 & 63 \\
\hline
\end{tabular}

Table 5. Facilities for patient decontamination 
M. Edgell \&

M.R. James therefore ensure that suitable personal protective equipment, including clothing, is provided to employees who may be exposed to a risk to their health whilst at work. The employee must also be given adequate information, instruction and training to enable him to know the protection provided by the equipment and its uses and limitations. ${ }^{4}$ We found that the majority of designated hospitals were aware of access to monitoring equipment but the reverse was true in the other hospitals. (Table 1). The results show that nearly half of the designated hospitals and approximately three quarters of the non-designated hospitals lacked basic items to minimize the spread of contamination and to protect staff. It is apparent that training facilities and exercises are lacking in a large proportion of both types of hospital but particularly in the nondesignated ones. However, even in the designated hospitals the training facilities appear to fall far short of those recommended.

Many of the $76 \%$ of designated hospitals (Table 4) who stated that radioactively contaminated water could be put down the main drain had been misinformed as this is illegal with $\alpha$-emitting radioisotopes, which may be involved in these contamination incidents. It is obviously difficult to generate and maintain interest in safe practice for unlikely occurrences, particularly when staff change frequently, but Department of Health guidance states that 'the readiness of staff to perform this role is maintained by adequate training and exercising' ${ }^{2}$ It is essential that the hospitals that the Regions designate 'can be equipped and staffed to perform these roles'.2 The authors do not believe that this has been achieved in most A\&E departments and yet much of the application of safer handling, including waste containment, could be used in the more likely event of treating the injured patient who is chemically contaminated.

\section{REFERENCES}

1. NAIR Handbook (1987) National Radiological Protection Board. Revised edition, NRPB, Chilton, Didcot, Oxon OX11 ORQ.

2. Department of Health (1989) Health Services Arrangements for Dealing with Accidents Involving Radioactivity. $\mathrm{HC}(89) 8 / \mathrm{HN}(\mathrm{FP})(89) 8$. HMSO, London.

3. Department of Health (1989) Annexe to $\mathrm{HC}(89) 8$ / HN(FP)(89)8. HMSO, London.

4. Health \& Safety - Personal Protective Equipment at Work Regulations (1992) No 29966. HMSO, London. 